\title{
Disparity between planktonic fish egg and larval communities as indicated by DNA barcoding
}

\author{
Scott E. Burghart, Lauren Van Woudenberg, Camille A. Daniels, \\ Steven D. Meyers, Ernst B. Peebles, Mya Breitbart* \\ College of Marine Science, University of South Florida, 140 7th Avenue South, Saint Petersburg, Florida 33701, USA
}

\begin{abstract}
A genetic identification method (DNA barcoding) was used to compare the community compositions of planktonic fish eggs and larvae within a coastal embayment, testing the hypothesis that the composition of the planktonic larval fish community proportionately reflects the composition of the planktonic fish egg community (excluding species with non-planktonic eggs). By genetically identifying 843 individual eggs, we preserved the quantitative aspects of traditional community analysis. The studied embayment has restricted hydrodynamic connectivity to other coastal waters. A circulation model containing simulated particles estimated average egg movement of approximately $1 \mathrm{~km}$ between times of spawning and sample collection, indicating locally spawned eggs were likely to be retained within the survey area. Thirteen of 14 collected egg taxa ( $88 \%$ of egg specimens) could be genetically identified to species level, with the 14th taxon identified to genus level. This novel approach revealed a high degree of spatial heterogeneity in fish egg compositions within the embayment. Species that dominated the egg community (Eugerres plumieri, Cynoscion nebulosus, Centropomus undecimalis, and Prionotus spp.) were not particularly abundant amongst the 276 larvae identified, and the most abundant larval species (Achirus lineatus and Cynoscion arenarius) only comprised a minor proportion of the identified eggs. Overall, there was no correlation between the percent compositions of the egg and larval communities $(\mathrm{r}=-0.07, \mathrm{n}=15, \mathrm{p}=0.81)$. The clear disparities observed between the species compositions of the egg and larvae highlight the need for directly identifying eggs when studying habitat connectivity or performing stock assessment with egg production model-based methods.
\end{abstract}

KEY WORDS: PCR - Daily egg production method - Fish spawning - Genomics · Biodiversity · Habitat connectivity · Marine protected area

\section{INTRODUCTION}

The declining state of fisheries in many parts of the world, combined with the call for more fisheries-independent monitoring, highlights the need for novel ways of identifying and assessing the dynamics of fish populations (Cadrin et al. 2005). Fish life cycles often involve development stages with different habitat needs, which are reconciled by adult movement to spawning grounds, followed by egg and larval dispersal, and then migration to habitats used by pre-adult and adult stages (Steneck \& Wilson 2010).
Toward this end, the identification and enumeration of fish eggs and larvae is useful for several reasons. Because the eggs of many species drift passively and have known development times, the presence of eggs can reveal spawning locations. Egg production models (EPMs) have been used to calculate spawning stock biomass (reviewed in Stratoudakis et al. 2006). Additionally, egg and larval distributions provide information about both the dispersal mechanisms (Hare 2005) and the magnitude of different habitat connectivities (Piñeda et al. 2007), processes that are critical to the design of marine protected areas. 
Investigations of planktonic fish eggs are often limited by the ability to correctly identify taxa of interest. Species identification may be difficult due to the lack of distinguishing visible characters. This is particularly true in the case of highly speciose percomorph fish eggs (Holt et al. 1988, Daniel \& Graves 1994, García-Vázques et al. 2006, Carreon-Martinez et al. 2010), often meaning that only broad taxonomic categories are reported. Molecular methods have gained popularity for fish species identification, and are especially useful in cases where visual identification is difficult or impossible (reviewed by Teletchea 2009). Genetic identification of eggs has proved to be the most reliable molecular method (Shao et al. 2002), and is being increasingly used to provide definitive, species-specific information on egg distribution and abundance. In some cases, genetic identification has demonstrated that assumptions about the species composition of a spawning assemblage can lead to erroneous conclusions (Shao et al. 2002, Fox et al. 2005). For example, an ichthyoplankton survey in the Irish Sea by Fox et al. (2005) genetically demonstrated that only $38 \%$ of 'cod-like eggs', which were assumed to be cod in a previous morphologybased stock assessment, actually originated from cod. In this case, significant misidentification of whiting and haddock eggs as cod eggs likely generated falsely elevated estimates of cod spawning stock biomass.

Genetic identification of eggs is usually limited to one or a few targeted species to provide information on spawning location (Aoyama et al. 2001, Akimoto et al. 2002, Watanabe et al. 2004, Hyde et al. 2005, Carreon-Martinez et al. 2010), spawning season (Carreon-Martinez et al. 2010), or egg abundance (Fox et al. 2005, Karaiskou et al. 2007, Bayha et al. 2008). Several studies have attempted to correlate microscopic and genetic identification techniques, especially targeting eggs that could not be definitively identified by microscopy (Shao et al. 2002, Kawakami et al. 2010, Lelièvre et al. 2012). Towards a more comprehensive and high-throughput approach, suspension bead arrays have also been designed that can detect the presence of at least 23 different marine fish species (Gleason \& Burton 2012). However, the vast majority of studies are still restricted to detecting a small number of targeted species and, moreover, detections using the suspension-bead approach are limited to presence-absence information. While targeting the eggs of specific species of interest is an appropriate strategy for some purposes, a practical method capable of quantifying all egg species present has direct utility to biogeographical, ecological, and EPM-based investigations. To our knowledge, only a single study has genetically analyzed fish-egg communities to gain an overview of the species composition of a natural assemblage (Saitoh et al. 2009).

Although several marker genes have been employed for genetic identification (DNA barcoding) of fishes, the most commonly utilized gene is the mitochondrial cytochrome $c$ oxidase 1 (COI) gene, which can distinguish the vast majority of described species (Teletchea 2009, Ward et al. 2009, Bucklin et al. 2011). The inception of the Fish Barcode of Life Initiative (FISH-BOL) in 2005 launched a concerted effort to barcode fishes in a standardized manner (Ward et al. 2009). As of July 2010, 7800 fish species had been barcoded, a number comprising approximately $25 \%$ of the fish species currently known, with at least one species from $89 \%$ of all known fish families barcoded (Becker et al. 2011). The availability of universal M13-tailed primer cocktails to amplify the fish COI gene enables high-throughput identification of fish species in taxonomically diverse samples (Ivanova et al. 2007). This approach is especially valuable when applied to fish eggs.

In this paper, we compare the community compositions of planktonic fish eggs and larvae that were collected simultaneously, testing the hypothesis that the composition of the planktonic larval fish community proportionately reflects the composition of the planktonic fish egg community. We use genetic methods to identify individual eggs, and thereby preserve the quantitative aspects of genome-based community analysis. We conducted this comparison in a small embayment that has restricted hydrodynamic connectivity to other coastal waters, and describe the connectivity between egg and larval stages using a circulation model.

\section{MATERIALS AND METHODS}

\section{Study area}

The $15.6 \mathrm{~km}^{2}$ Terra Ceia Bay (TCB) is located within the Terra Ceia Aquatic Preserve, an $88 \mathrm{~km}^{2}$ area of submerged and tidal wetland (primarily mangrove) habitat bordering the southern shore of Tampa Bay, Florida, USA (Fig. 1). Relative to much of the Tampa Bay area, land surrounding the Terra Ceia Aquatic Preserve has received only moderateto-low amounts of development. The area is known to be an important spawning and nursery habitat for coastal fish (Hayslip 2013). 


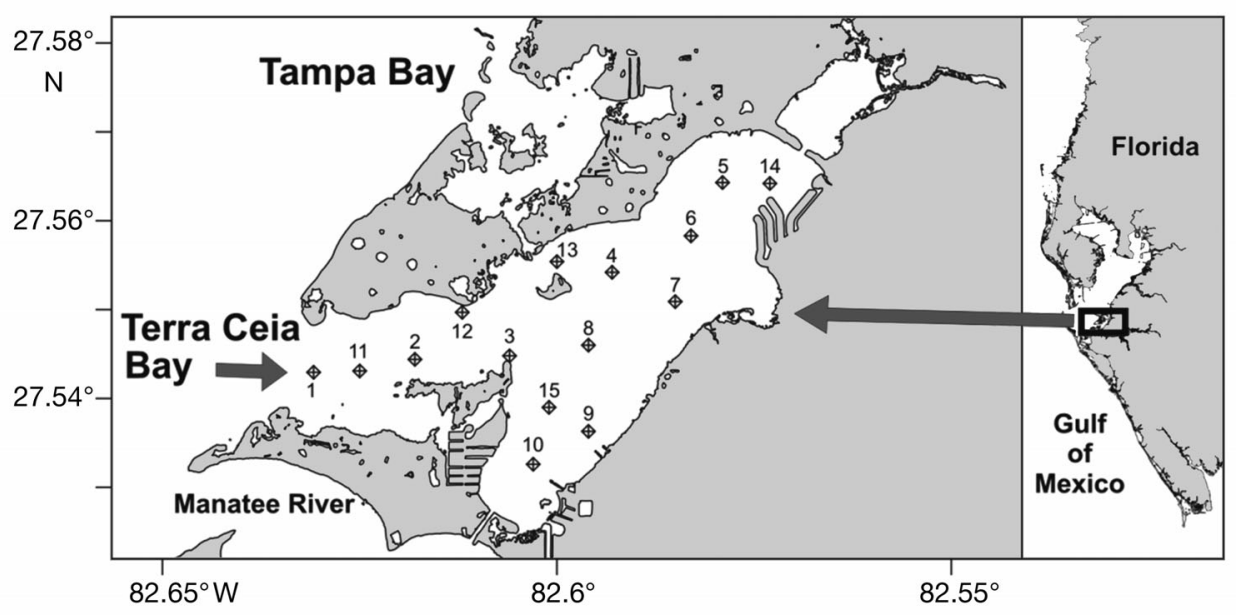

Fig. 1. Location of Terra Ceia Bay on the west coast of Florida and locations of 15 stations used in the ichthyoplankton survey. Stations are numbered by order of collection

\section{Egg and larval survey}

Fish eggs and larvae were collected using a flowmeter-equipped plankton net $(0.5 \mathrm{~m}$ mouth, $333 \mu \mathrm{m}$ mesh, 3:1 aspect ratio) towed for $1 \mathrm{~min}$ near bottom, midwater, and surface depths $(3 \mathrm{~min}$ oblique tow) at 15 stations on 9 June 2011 between 07:00 and 11:00 h. The 15 stations were visited in the numerical sequence indicated in Fig. 1; the reversing sequence was intended to disrupt trends caused by advection-related spatial aliasing. Samples were preserved in the field in $50 \%$ isopropanol in ambient seawater.

Upon return to the laboratory, fish eggs and larvae were identified at 70-900× magnification using an Olympus SZX 12 stereomicroscope. Most percomorph eggs were not reliably identifiable and were separated from clupeoid eggs (anchovies, sardines, and herrings). Individual percomorph eggs were transferred to $50 \%$ isopropanol in $0.02 \mu \mathrm{m}$ filtered seawater in individual glass vials. In some samples, all percomorph eggs ('eggs') were removed for genetic identification. When eggs were numerous $(>100)$ within a sample, a subsample was removed for genetic analysis and the total number of eggs was prorated according to the genetic identification results. Egg densities (eggs $\mathrm{m}^{-3}$ ) were contoured by kriging (linear semivariogram method) using Surfer 9.11.947 (Golden Software).

The eggs of some species (gobiids and blenniids) are normally attached to substrate and rarely occur in ichthyoplankton samples; other species exhibit brooding behavior (Sygnathus spp.). These taxa were excluded from comparisons of planktonic egg and larval assemblages.

\section{Genetic egg identification}

Individual eggs sorted for genetic identification were placed into different wells of a 96-well PCR plate. Eggs were rehydrated in $10 \mu \mathrm{l}$ of sterile water for $15 \mathrm{~min}$, and then the water was removed from each well. After rehydration, DNA was extracted following methods adapted from Hyde et al. (2005). Briefly, $150 \mu l$ of $10 \%$ Chelex 100 Molecular Biology Grade Resin (Bio-Rad Laboratories) was added to each well and individual eggs were crushed using a sterile toothpick. The plates were then incubated in a thermocycler at $60^{\circ} \mathrm{C}$ for $20 \mathrm{~min}$, followed by $99^{\circ} \mathrm{C}$ for $20 \mathrm{~min}$, then cooling to $4^{\circ} \mathrm{C}$. To genetically identify the fish eggs, the COI- 3 universal fish primer cocktail was employed to amplify the barcoding region of the COI gene (Ivanova et al. 2007). The COI-3 primer cocktail contains flanking M13 tails, which eliminate the need for cloning and enable high-throughput sample processing. The $50 \mu \mathrm{l}$ PCR reaction contained final concentrations of $1 \times$ Apex $\mathrm{NH}_{4}$ buffer, $1.5 \mathrm{mM}$ Apex $\mathrm{MgCl}_{2}, 0.2 \mu \mathrm{M}$ Apex dNTPs, $1 \mathrm{U}$ Apex Red Taq (Genesee Scientific), $0.2 \mu \mathrm{M}$ of the COI-3 primer cocktail, $10 \mu \mathrm{g} \mathrm{l}^{-1}$ bovine serum albumin (ThermoFisher), and $1 \mu \mathrm{l}$ of the supernatant from the Chelex egg extraction. The thermocycler profile consisted of $94^{\circ} \mathrm{C}$ for $2 \mathrm{~min}$; followed by 45 cycles of $94^{\circ} \mathrm{C}$ for $30 \mathrm{~s}, 52^{\circ} \mathrm{C}$ for $40 \mathrm{~s}$, and $72^{\circ} \mathrm{C}$ for $1 \mathrm{~min}$; and a final extension at $72^{\circ} \mathrm{C}$ for $10 \mathrm{~min}$. Successful PCR amplification was confirmed on a $1 \%$ agarose gel stained with ethidium bromide, and PCR products were directly sequenced with the M13F primer by Beckman Coulter Genomics. Sequences were trimmed for quality using Sequencher (GeneCodes) and compared against the species level records in the Barcode of Life Database (BOLD; www.boldsystems.org/) for identification. 


\section{Hindcasting of spawning locations}

To determine whether eggs were spawned inside or outside $\mathrm{TCB}$, a realistic numerical circulation model was used with passively advected, buoyant, simulated Lagrangian particles ('particles'). The circulation model is based on the 3-dimensional Estuarine and Coastal Ocean Model (ECOM-3D), which is a variation of the Princeton Ocean Model (Blumberg \& Mellor 1987); it was developed for Tampa Bay by Vincent (2001) to examine regional-scale circulation, and particle tracer code was subsequently developed by Burwell (2001). The model uses a curvilinear grid of 2248 cells fit to the coastline, with an average horizontal grid cell size of $668 \mathrm{~m}$. The vertical dimension was sectioned by 11 terrain- following sigma layers. Boundary conditions for the model are taken from observations; thus model output is associated with specific dates and times (Fig. 2). Previous work with this model has demonstrated that its output accurately recreates elevation, transport, and salinity; model errors are small compared with observed values (Meyers et al. 2014). The Lagrangian advection scheme is essentially 3dimensional Euler steps of the velocity field at the model time interval (1 min), as defined at the location of each particle by linear interpolation from nearest gridpoints. Meyers \& Luther (2008) present a more detailed description of the model's advective scheme.

For hindcasts of spawning locations, we assumed a generalized spawning time of $2.5 \mathrm{~h}$ after sunset.
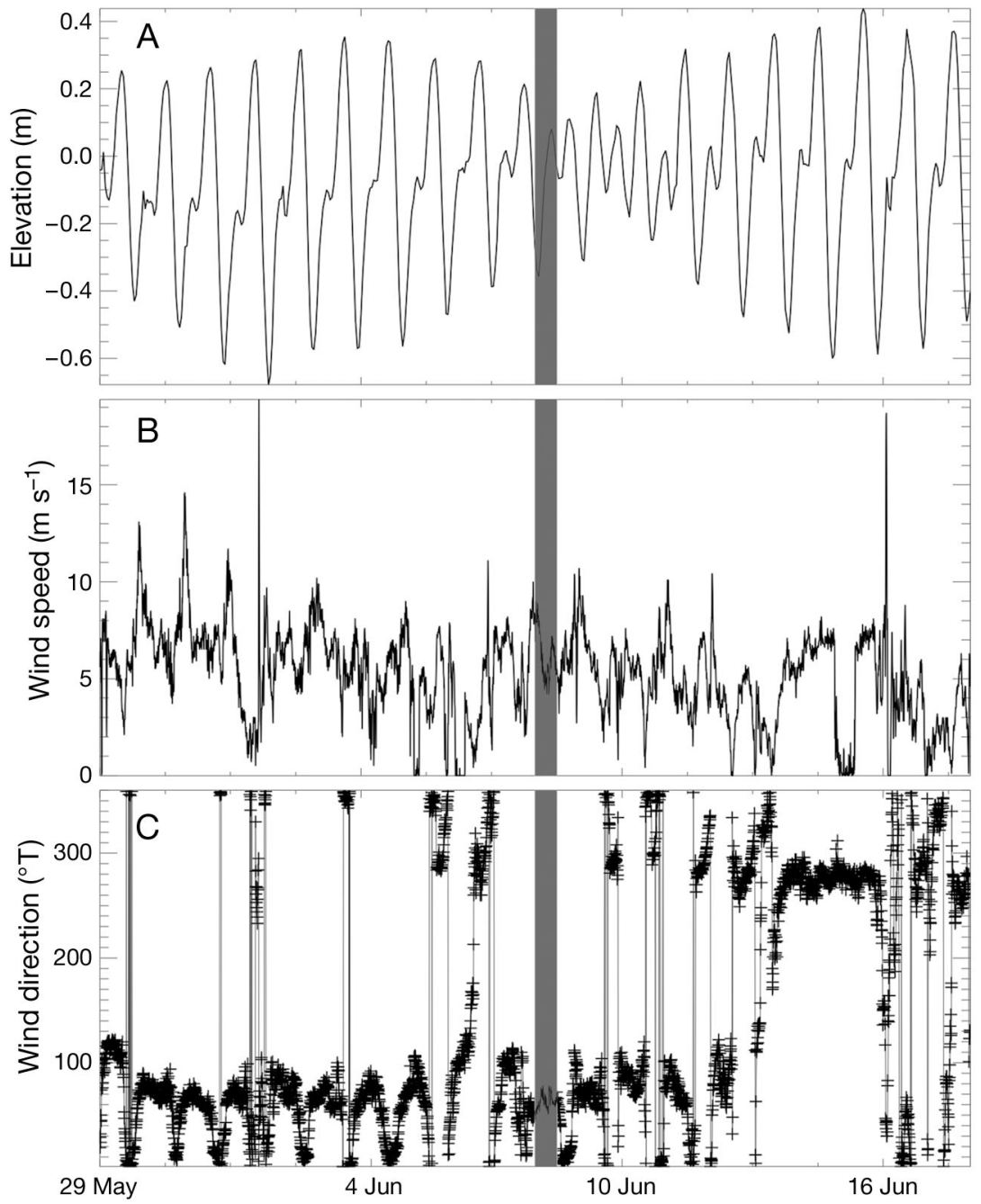

Fig. 2. Model boundary conditions as (A) elevation at the mouth of Tampa Bay, (B) wind speed, and (C) wind direction (in degrees True, ${ }^{\circ} \mathrm{T}$ ). The time interval over which eggs are released and tracked is indicated in gray 
A total of 140000 particles were released uniformly throughout the area of TCB on 8 June 2011 at 23:00 h, which was approximately $6-10 \mathrm{~h}$ prior to the ichthyoplankton survey. The particles were distributed evenly throughout the upper 2 sigma layers (9\% of the water column) with fixed relative depths. Particles were advected by the model horizontal velocity field for $24 \mathrm{~h}$, simulating conditions with and without observed wind. The mean distance $(d)$ of the eggs from their origin is calculated using the position of each egg $i$ at position $\left(x_{\mathrm{i}}(t), y_{\mathrm{i}}(t)\right)$ and their origin $\left(x_{\mathrm{i}}(0), y_{\mathrm{i}}(0)\right)$ as:

$$
d(t)=\left[N^{-1} \sum_{i=1}^{N}\left[x_{i}(t)-x_{i}(0)\right]^{2}+\left[y_{i}(t)-y_{i}(0)\right]^{2}\right]^{1 / 2}
$$

where $N$ is the total number of eggs in the simulation and $t$ is time.

\section{RESULTS}

\section{Spawning location}

Time intervals between simulated particle release and net collection ranged from 6 to $9.8 \mathrm{~h}$, depending on station, with average interval of $7.9 \mathrm{~h}$. With wind effects included, this equated to an average horizontal displacement of approximately $1 \mathrm{~km}$ (Fig. 3). Based on the size of the bay and locations of the egg aggregations (Fig. 4), this suggests that spawning was primarily restricted to the interior of $\mathrm{TCB}$, with relatively low opportunity for advection of eggs into or out of the study area. The estimated origin of particles for each station was variable (Fig. 5), yet for stations in eastern TCB, estimated spawning positions were restricted to the easternmost part of TCB, and particle origins for centrally located stations were generally to the north and east of the stations and were spread over relatively large areas (Fig. 5).

\section{Genetic egg identification}

Preservation in $50 \%$ isopropanol did not interfere with successful genetic identification of fish eggs. A total of 843 eggs from 15 stations were genetically identified as belonging to 14 fish taxa. In only 3

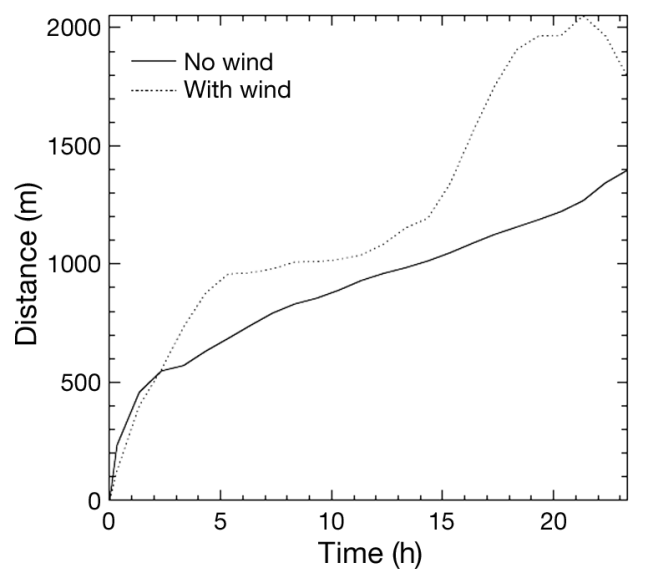

Fig. 3. Average egg dispersal distance over time, with and without wind effects in Fig. 2. The ichthyoplankton survey was conducted between hours 8 and 12

\section{$\begin{array}{lllllllll}32 & 28 & 24 & 20 & 16 & 12 & 8 & 4 & 0\end{array}$}

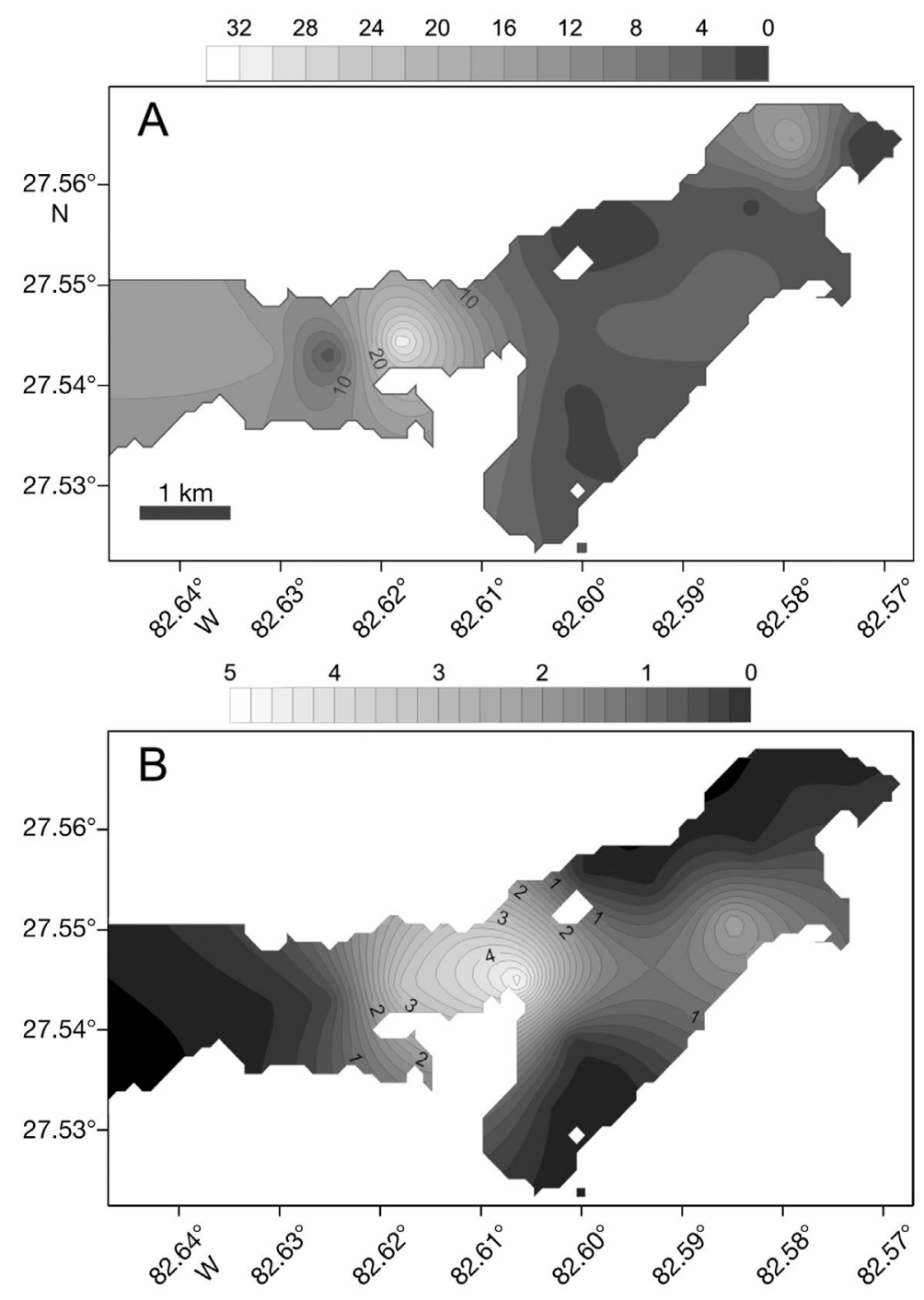

Fig. 4. Density and distribution of (A) all fish eggs in Terra Ceia Bay and (B) common snook Centropomus undecimalis eggs. The scale is eggs $\mathrm{m}^{-3}$ 

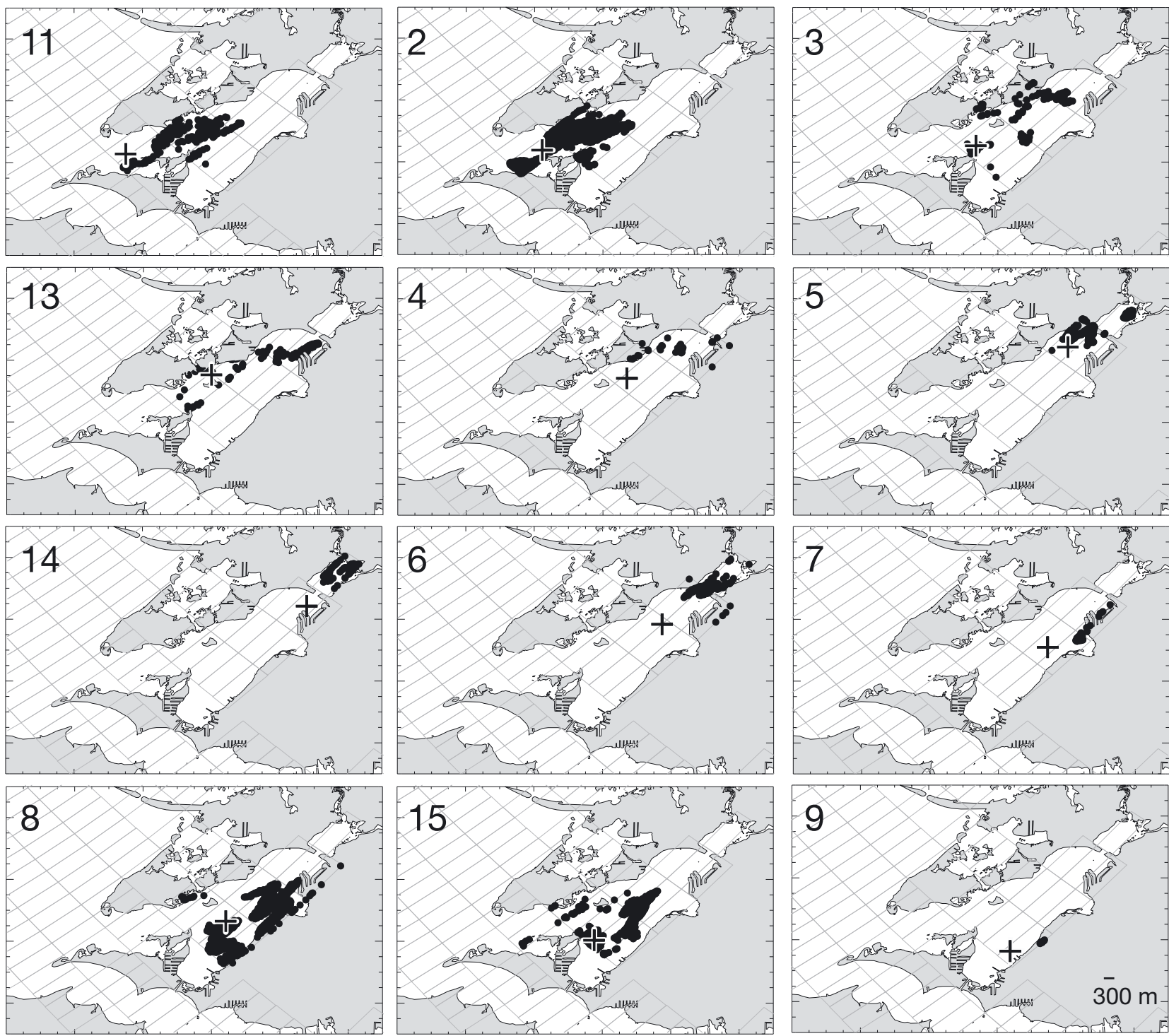

Fig. 5. Hindcast particle origins for each station (crosses) in the ichthyoplankton survey. Stns 1, 10, and 12 had no particles within the search radius during the generalized spawning time $(23: 00 \mathrm{~h})$. Gray lines depict the model grid

instances could a species not be assigned using the BOLD database (Bairdiella spp., Prionotus spp., and Chilomycterus spp.). For Bairdiella and Chilomycterus, there is only 1 species of each that occurs in the area, B. chrysoura and C. schoepfi. Proration extended the total number of identified eggs to 4467 (Table 1). Among these, $91 \%$ belonged to 5 species: striped mojarra Eugerres plumieri $(33.6 \%)$, spotted seatrout Cynoscion nebulosus $(21.9 \%)$, common snook Centropomus undecimalis $(15.3 \%)$, sea robins Prionotus spp. (12.2\%), and southern kingfish Menticirrhus americanus (8.1\%) (Table 2).

Egg species composition was spatially heterogeneous, with different compositions occurring in close proximity (Fig. 6). Individual species occurred at 1 to 14 stations (average $=6$ stations), with no single species found at every station. Species richness varied widely among stations, with as few as 2 or as many as 9 species detected (average $=6$ species). Many eggs were concentrated immediately east of the mouth of TCB (Fig. 4A). There was a secondary peak in abundance at the head of TCB that was due almost entirely to Eugerres plumieri. The largest aggregation of C. undecimalis eggs occurred near Stn 3 (Figs. 4B \& 6).

A total of 276 larvae from 21 taxa were identified (Table 1). Species with attached eggs (i.e. blennies and gobies) or brooded eggs (Sygnathus spp.) 
Table 1. Catch summary (number of individuals collected) of ichthyoplankton from Terra Ceia Bay. Taxa with attached or brooded eggs are shaded gray

\begin{tabular}{|lccc|}
\hline Taxon & Eggs & Larvae & Total \\
\hline Achirus lineatus & 28 & 45 & 73 \\
Unidentified blenniids & 0 & 25 & 25 \\
Bairdiella chrysoura & 70 & 20 & 90 \\
Bathygobius soporator & 0 & 14 & 14 \\
Caranx hippos & 5 & 0 & 5 \\
Centropomus undecimalis & 682 & 2 & 684 \\
Chaetodipterus faber & 96 & 0 & 96 \\
Chasmodes saburrae & 0 & 7 & 7 \\
Chilomycterus schoepfi & 4 & 0 & 4 \\
Chloroscombrus chrysurus & 84 & 1 & 85 \\
Cynoscion arenarius & 74 & 46 & 120 \\
Cynoscion nebulosus & 979 & 16 & 995 \\
Eucinostomus spp. & 0 & 2 & 2 \\
Eugerres plumieri & 1499 & 0 & 1499 \\
Gobiosoma spp. & 0 & 7 & 7 \\
Unidentified gerreids & 0 & 7 & 7 \\
Unidentified gobiids & 0 & 31 & 31 \\
Menticirrhus americanus & 362 & 0 & 362 \\
Menticirrhus spp. & 0 & 23 & 23 \\
Oligoplites saurus & 26 & 9 & 35 \\
Prionotus spp. & 547 & 9 & 556 \\
Sygnathus floridae & 0 & 2 & 2 \\
Sygnathus louisianae & 0 & 3 & 3 \\
Sygnathus scovelli & 0 & 3 & 3 \\
Trinectes maculatus & 11 & 1 & 12 \\
Unidentified fish & 0 & 3 & 3 \\
Totals & 4467 & 276 & 4743 \\
\hline
\end{tabular}

Table 2. Comparison of egg and larval compositions from Table 1, excluding taxa with attached or brooded eggs and assuming likely identities of 2 larval types. Taxa are ranked in decreasing order by their abundance in the egg community

\begin{tabular}{|c|c|c|c|c|}
\hline \multirow[t]{2}{*}{ Taxon } & \multicolumn{2}{|c|}{ Eggs } & \multicolumn{2}{|c|}{ Larvae } \\
\hline & $\mathrm{n}$ & $(\%)$ & $\mathrm{n}$ & $(\%)$ \\
\hline Eugerres plumieri & 1499 & 33.6 & $7^{\mathrm{a}}$ & 3.9 \\
\hline Cynoscion nebulosus & 979 & 21.9 & 16 & 8.8 \\
\hline Centropomus undecimalis & 682 & 15.3 & 2 & 1.1 \\
\hline Prionotus spp. & 547 & 12.2 & 9 & 5.0 \\
\hline Menticirrhus americanus & 362 & 8.1 & $23^{b}$ & 12.7 \\
\hline Chaetodipterus faber & 96 & 2.1 & 0 & 0.0 \\
\hline Chloroscombrus chrysurus & 84 & 1.9 & 1 & 0.6 \\
\hline Cynoscion arenarius & 74 & 1.7 & 46 & 25.4 \\
\hline Bairdiella chrysoura & 70 & 1.6 & 20 & 11.0 \\
\hline Achirus lineatus & 28 & 0.6 & 45 & 24.9 \\
\hline Oligoplites saurus & 26 & 0.6 & 9 & 5.0 \\
\hline Trinectes maculatus & 11 & 0.2 & 1 & 0.6 \\
\hline Caranx hippos & 5 & 0.1 & 0 & 0.0 \\
\hline Chilomycterus schoepfi & 4 & 0.1 & 0 & 0.0 \\
\hline Eucinostomus spp. & 0 & 0.0 & 2 & 1.1 \\
\hline Totals & 4467 & 100.0 & 188 & 100.0 \\
\hline \multicolumn{5}{|c|}{ 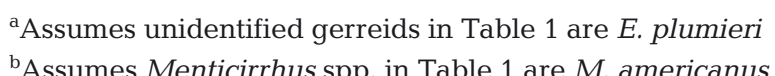 } \\
\hline
\end{tabular}

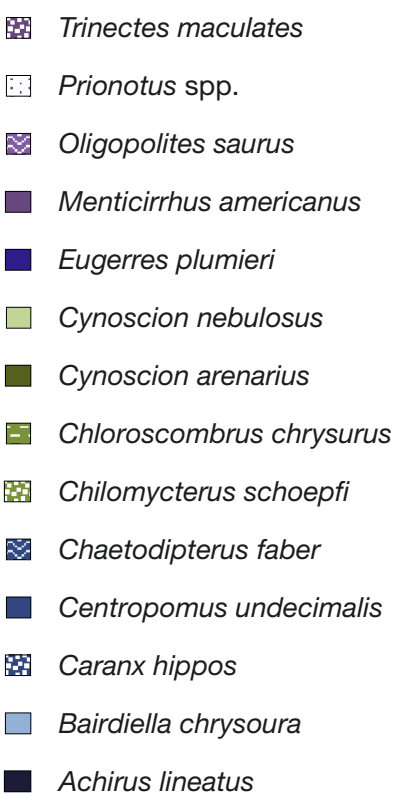

Fig. 6. Species composition of planktonic eggs at stations within Terra Ceia Bay. Stations are ordered from west to east

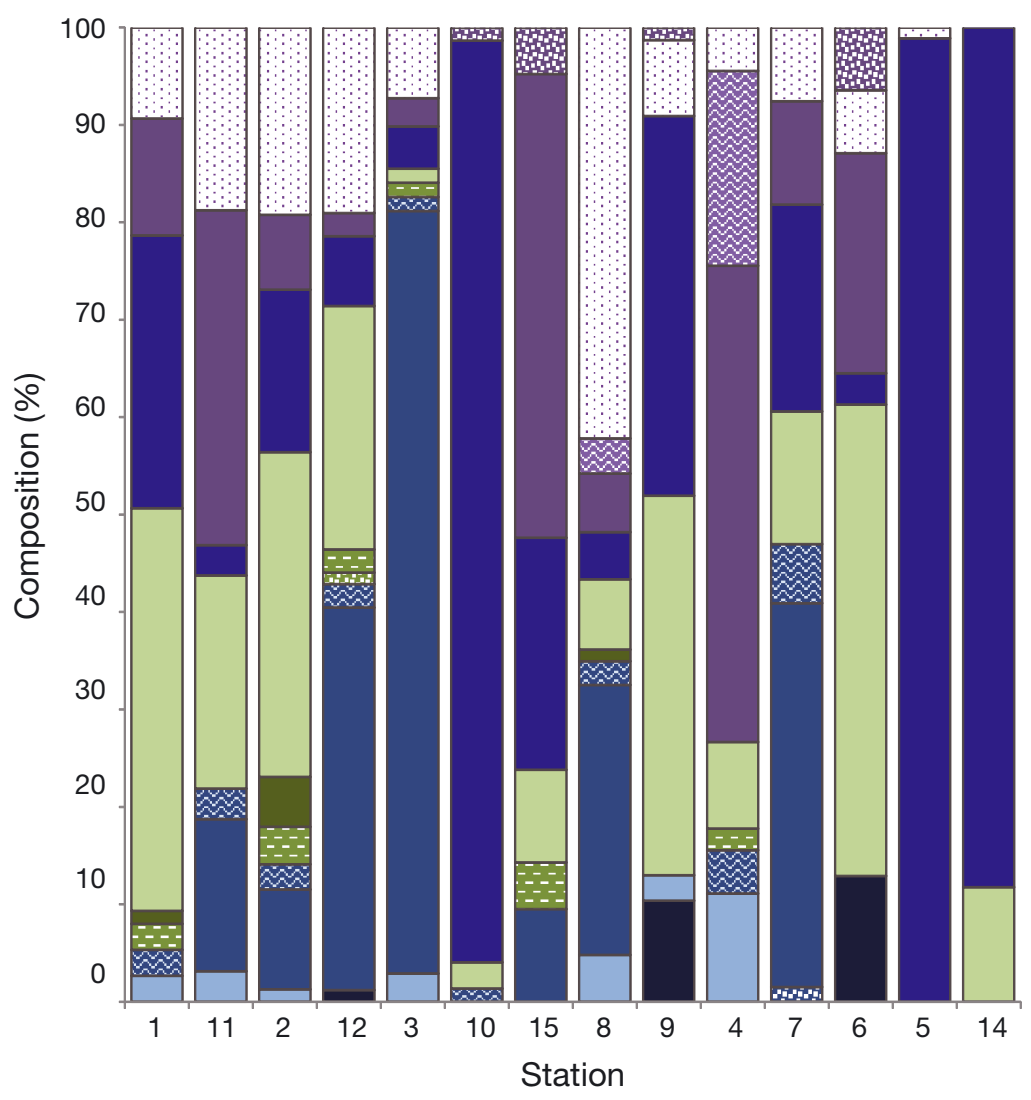


accounted for 8 of the 21 larval taxa and $33.3 \%$ of the total larvae collected, and indeed no eggs belonging to these species were identified in the ichthyoplankton survey (Table 1). Some taxa listed separately in Table 1 likely belong to the same species. These include preflexion stages of kingfish (Menticirrhus spp.), which cannot be definitively identified to species; however, all eggs collected were identified as M. americanus. Also, larvae listed as unidentified gerreids are likely to be Eugerres plumieri. These likely identities are reflected in Table 2. Larvae of 11 of the 14 egg species were identified, with only Caranx hippos, Chaetodipterus faber, and Chilomycetus shoepfi not being represented in the larval community. Only a single larval taxon known to have planktonic eggs (Eucinostomus spp.) was collected in the absence of corresponding eggs.

\section{Comparison of egg and larval compositions}

Percent compositions of the egg and larval communities, exclusive of taxa with attached or brooded eggs, are presented in Table 2. There was no evidence of correlation between the percent compositions of the egg and larval communities shown in Table $2(\mathrm{r}=-0.07, \mathrm{n}=15, \mathrm{p}=0.81)$. Although $>75 \%$ of taxa were collected as both eggs and larvae, the relative abundance of each stage was highly variable. None of the taxa that dominated the egg community (Eugerres plumieri, Cynoscion nebulosus, Centropomus undecimalis, and Prionotus spp.) were particularly abundant in the larval community, and the most abundant larval taxa (Cynoscion arenarius and Achirus lineatus) comprised minor proportions of the egg community.

\section{DISCUSSION}

Given the readily detected disparity between egg and larval communities, which is accentuated by the fact that some species that are present as eggs can be rare or apparently absent as larvae, there is compelling reason to believe that the biodiversity of planktonic fish eggs remains largely undescribed at multiple spatial scales and that assumptions concerning correspondence between planktonic egg and larval community compositions can be incorrect. The disparity between the egg and larval community compositions does not seem to be dominated by advection, as the hindcast results indicated the majority of eggs spawned within TCB would remain within the bay.
There are also more singular implications from the present results. Species that are thought to exclusively spawn in one type of habitat may have small numbers of eggs in unexpected locations. For example, spawning by the crevalle jack Caranx hippos is thought to take place at $40-180 \mathrm{~m}$ depths on the mid-to-outer continental shelf in the Gulf of Mexico (Ditty et al. 2004), yet 5 eggs were positively identified from $<5 \mathrm{~m}$ depth well inside a small embayment (Stn 7 in TCB). Because the initial seeding of modeled particles encompassed TCB but did not extend seaward of the mouth of TCB, there were likely some incursions of egg-bearing, flood-tide waters into the mouth of TCB that were not reflected in the hindcast results. Habitat connectivities may thus become established from variable distances and at earlier stages than is usually considered, particularly when such stages are difficult to recognize visually.

The common snook Centropomus undecimalis provides another example. Snook larvae are rarely collected by plankton nets (Tolley et al. 1987) and only 2 snook larvae were collected during the present survey, yet adults are known to broadcast-spawn within TCB (Taylor et al. 1998, Hayslip 2013) and juveniles are locally abundant in landward mangrove areas adjacent to TCB (Brame et al. in press). Snook eggs were the third most abundant egg type in the survey, and they occurred in very close proximity to the mangrove habitats used by juveniles. Estimates of spawning positions associated with Stn 3 (Fig. 5), where snook eggs were abundant, indicate the eggs came from well inside the bay rather than the bay mouth. Given that the prevailing wind direction during the study was from the east (Fig. 2), and that egg transport was partly wind-driven (Fig. 3), spawning further inside the bay would increase the probability of larval settlement in proximal nursery habitat. It is thus likely that recruitment to mangrove habitats is sometimes facilitated early on by the distribution of eggs (e.g. common snook and striped mojarra Eugerres plumieri), reducing the need for late-stage larvae to reconcile the spatial gap between spawning sites and landward nursery habitats. A similar conclusion may be drawn for spotted seatrout Cynoscion nebulosus, which were abundant as eggs in the water column above the seagrass meadows in TCB that are used as juvenile nursery habitat, but were relatively rare as larvae in the water column (Table 2).

Conversely, the commonly collected larvae of other species (e.g. sand seatrout Cynoscion arenarius and lined sole Achirus lineatus) may be actively involved in migration to juvenile habitats, employing behavioral drift mechanisms such as selective tidal stream 
transport (Hill 1991) that make them more likely to be collected by plankton nets even at locations where their eggs are rare (Table 2).

Hindcasts indicated most eggs originated from spawning events within TCB. The eastward bias of the particle origins is partly due to prevailing easterly winds. The high degree of spatial heterogeneity in egg community composition (Fig. 6) could reflect a combination of spawning microhabitats for individual species, temporal variation in egg release, and circulation (Norcross \& Shaw 1984). In addition, the observation of spatial heterogeneity in egg composition highlights the potential need for extensive sampling at fine spatial scales to elucidate the complete spawning community in a given area.

Compared with other molecular methods that target a limited number of fish species, the community analysis approach used in this study enabled determination of the complete spawning population diversity without prior assumptions about the species present. Although this sequence-based approach is more expensive than PCR- or microarray-based assays targeting a limited number of fish species, it has the advantage of identifying each individual egg, providing quantitative data, and revealing species not previously thought to be present. In addition, since this method does not rely on the availability of primers or probes for a given species, it can be used throughout the world, including regions for which limited sequence data are available. A hybrid approach could be employed (Gleason \& Burton 2012) where direct sequencing is only applied to eggs that fail to be identified through species-specific approaches, significantly reducing costs.

Overall, this novel molecular approach of sequencing DNA barcodes from individual fish eggs at multiple sites within an enclosed bay revealed a high degree of spatial heterogeneity and a high diversity of planktonic fish eggs. In addition, clear disparities between the species compositions of the eggs and larvae were observed, highlighting the need for directly identifying eggs when studying habitat connectivity or when using EPM-based stock assessment methods.

Acknowledgements. We extend our gratitude to Ralph Kitzmiller for managing the field component of this study as well as his contributing work in the lab.

\section{LITERATURE CITED}

Akimoto S, Kinoshita S, Sezaki K, Mitani I, Watabe S (2002) Identification of alfonsino and related fish species be- longing to the genus Beryx with mitochondrial 16s rRNA gene and its application on their pelagic eggs. Fish Sci 68:1242-1249

- Aoyama J, Ishikawa S, Otake T, Mochioka N and others (2001) Molecular approach to species identification of eggs with respect to determination of the spawning site of the Japanese eel Anguilla japonica. Fish Sci 67: 761-763

- Bayha KM, Graham WM, Hernandez FJ Jr (2008) Multiplex assay to identify eggs of three fish species from the northern Gulf of Mexico, using locked nucleic acid Taqman real-time PCR probes. Aquat Biol 4:65-73

Becker S, Hanner R, Steinke D (2011) Five years of FISHBOL: brief status report. Mitochondrial DNA 22:3-9

Blumberg A, Mellor GL (1987) A description of a threedimensional coastal ocean circulation model. In: Heaps NS (ed) Three-dimensional coastal ocean models. American Geophysical Union, Washington, DC, p 1-16

Brame AB, McIvor CC, Peebles EB, Hollander DJ (in press) Inclusion of site fidelity and condition metrics in the analysis of juvenile fish (common snook) habitat use. Mar Ecol Prog Ser

> Bucklin A, Steinke D, Blanco-Bercial L (2011) DNA barcoding of marine metazoa. Annu Rev Mar Sci 3:471-508

Burwell D (2001) Modeling the spatial structure of estuarine residence time: Eulerian and Lagrangian approaches. $\mathrm{PhD}$ dissertation, University of South Florida, St Petersburg, FL

Cadrin SX, Friedland KD, Waldman JR (eds) (2005) Stock identification methods: applications in fishery science. Elsevier Academic Press, Amsterdam

Carreon-Martinez L, Holt SA, Nunez B, Faulk C, Holt GJ (2010) The use of polymerase chain reaction for the identification of sciaenid eggs. Mar Biol 157:1889-1895

Daniel LB, Graves JE (1994) Morphometric and genetic identification of eggs of spring-spawning sciaenids in lower Chesapeake Bay. Fish Bull 92:254-261

Ditty JG, Shaw RF, Cope JS (2004) Distribution of carangid larvae (Teleostei: Carangidae) and concentrations of zooplankton in the northern Gulf of Mexico, with illustrations of early Hemicaranx amblyrhynchus and Caranx spp. larvae. Mar Biol 145:1001-1014

> Fox CJ, Taylor MI, Pereyra R, Villasana MI, Rico C (2005) Taqman DNA technology confirms likely overestimation of cod (Gadus morhua L.) egg abundance in the Irish Sea: Implications for the assessment of the cod stock and mapping of spawning areas using egg-based methods. Mol Ecol 14:879-884

García-Vázques E, Álvarez P, Lopes P, Karaiskou N, Perez J, Teia A, Martinez J, Gomes L, Triantaphillidis C (2006) PCR-SSCP of the 16s rRNA gene, a simple methodology for species identification of fish eggs and larvae. Sci Mar 70(Suppl 2):13-21

Gleason LU, Burton RS (2012) High-throughput molecular identification of fish eggs using multiplex suspension bead arrays. Mol Ecol Resour 12:57-66

Hare JA (2005) The use of early life stages in stock identification studies. In: Cadrin SX, Friedland KD, Waldman J (eds) Stock identification methods: applications in fisheries science. Elsevier Academic Press, San Francisco, CA, p 89-118

Hayslip CMB (2013) Investigation of condition effects on batch fecundity of the common snook, Centropomus undecimalis, in Tampa Bay, Florida. Master's thesis, University of South Florida, Tampa, FL 
Hill AE (1991) A mechanism for horizontal zooplankton transport by vertical migration in tidal currents. Mar Biol 111:485-492

Holt SA, Holt GJ, Young-Abel L (1988) A procedure for identifying sciaenid eggs. Contrib Mar Sci 50:99-108

Hyde JR, Lynn E, Humphreys R Jr, Musyl M, West AP, Vetter R (2005) Shipboard identification of fish eggs and larvae by multiplex PCR, and description of fertilized eggs of blue marlin, shortbill spearfish, and wahoo. Mar Ecol Prog Ser 286:269-277

Ivanova NV, Zemlak TS, Hanner RH, Hebert PD (2007) Universal primer cocktails for fish DNA barcoding. Mol Ecol Notes 7:544-548

Karaiskou N, Triantafyllidis A, Alvarez P, Lopes P, GarciaVazquez E, Triantaphyllidis C (2007) Horse mackerel egg identification using DNA methodology. Mar Ecol 28: 429-434

Kawakami T, Aoyama J, Tsukamoto K (2010) Morphology of pelagic fish eggs identified using mitochondrial DNA and their distribution in waters west of the Mariana Islands. Environ Biol Fishes 87:221-235

Lelièvre S, Jérôme M, Maes GE, Vaz S, Calaivany S, VerrezBagnis V (2012) Integrating molecular identification of pelagic eggs with geostatistical mapping to improve the delineation of North Sea fish spawning grounds. Mar Ecol Prog Ser 445:161-172

Meyers SD, Luther ME (2008) A numerical simulation of residual circulation in Tampa Bay. Part II: Lagrangian residence time. Estuaries Coasts 31:815-827

> Meyers SD, Linville A, Luther ME (2014) Alteration of residual circulation due to large-scale infrastructure in a coastal plain estuary. Estuaries Coasts 37:493-507

Norcross BL, Shaw RF (1984) Oceanic and estuarine transport of fish eggs and larvae: a review. Trans Am Fish Soc 113:153-165

Piñeda J, Hare JA, Sponaungle S (2007) Larval transport

Editorial responsibility: Janet Ley,

St. Petersburg, Florida, USA and dispersal in the coastal ocean and consequences for population connectivity. Oceanography 20:22-39

Saitoh K, Uehara S, Tega T (2009) Genetic identification of fish eggs collected in Sendai Bay and off Johban, Japan. Ichthyol Res 56:200-203

Shao KT, Chen KC, Wu JH (2002) Identification of marine fish eggs in Taiwan using light microscopy, scanning electron microscopy and mtDNA sequencing. Mar Freshw Res 53:355-365

Steneck RS, Wilson JA (2010) A fisheries play in an ecosystem theater: challenges of managing ecological and social drivers of marine fisheries at multiple spatial scales. Bull Mar Sci 86:387-411

Stratoudakis Y, Bernal M, Ganias K, Uriarte A (2006) The daily egg production method: recent advances, current applications and future challenges. Fish Fish 7:35-57

> Taylor RG, Grier HJ, Whittington JA (1998) Spawning rhythms of common snook in Florida. J Fish Biol 53:502-520

Teletchea F (2009) Molecular identification methods of fish species: reassessment and possible applications. Rev Fish Biol Fish 19:265-293

Tolley SG, Dohner ET, Peebles EB (1987) Occurrence of larval snook, Centropomus undecimalis (Bloch), in Naples Bay, Florida. Fla Sci 50:34-38

Vincent MS (2001) Development, implementation and analysis of the Tampa Bay coastal prediction system. PhD dissertation, College of Engineering, University of South Florida, St. Petersburg, FL

Ward RD, Hanner R, Hebert PD (2009) The campaign to DNA barcode all fishes, FISH-BOL. J Fish Biol 74: 329-356

Watanabe S, Minegishi Y, Yoshinaga T, Aoyama J, Tsukamoto K (2004) A quick method for species identification of Japanese eel (Anguilla japonica) using real-time PCR: an onboard application for use during sampling surveys. Mar Biotechnol 6:566-574

Submitted: December 6, 2013; Accepted: January 31, 2014 Proofs received from author(s): April 3, 2014 